
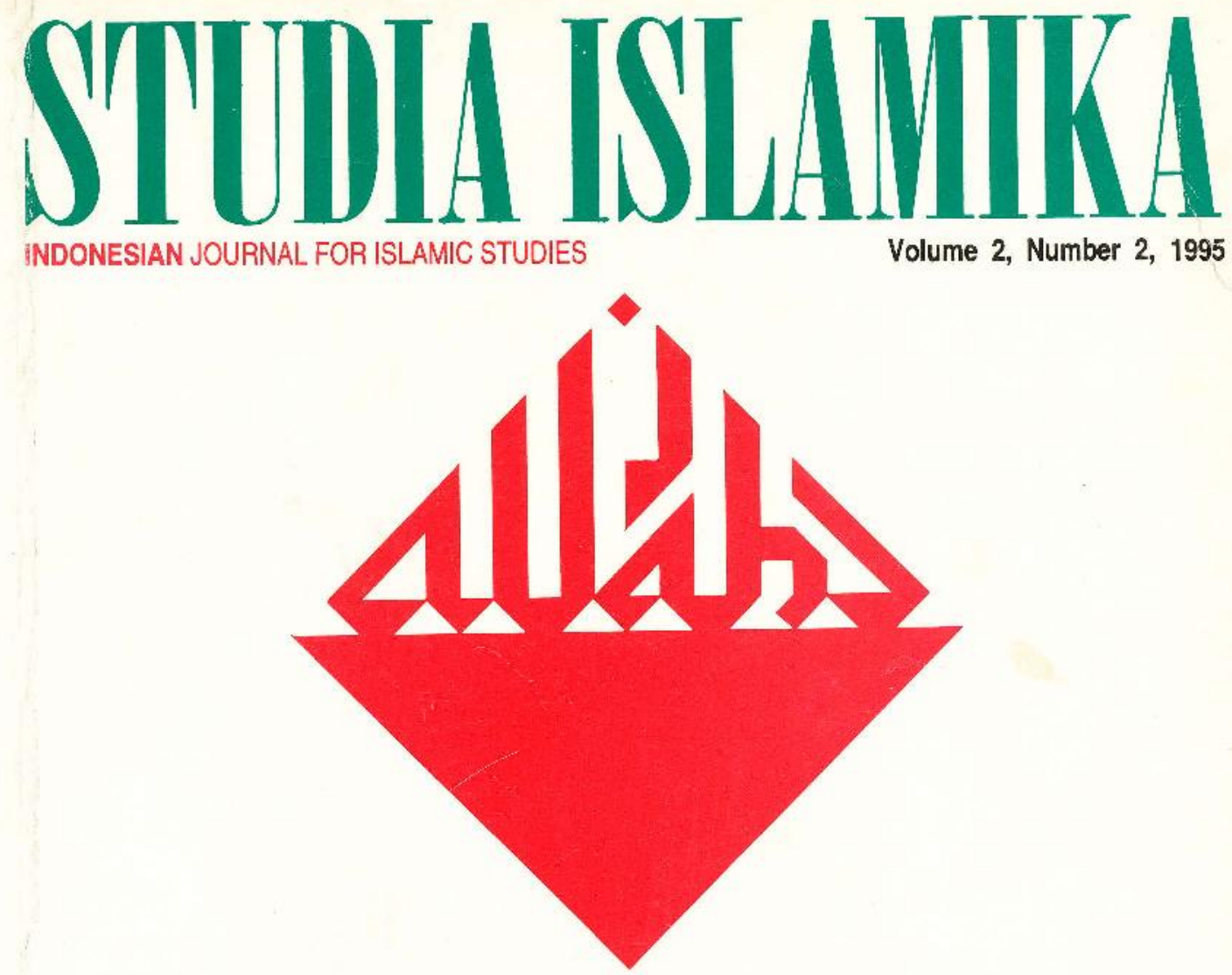

HADHRÂMÎSCHOLARS IN THE MALAY-INDONESIAN DIASPỌA:

A Preliminary Study of Sayyid 'Uthmân Azyumardi Azra

THE MUHAMmadiyah DA' WAH AND AlLOCATIVE POLITICS IN THE NEW ORDER M. Din Syamsuddin

QUR'ÂN INTERPRETATIONS OF HAMZAH FANSURI (CA.1600) AND HAMKA (1908-1982): A Comparison Karel Steenbrink

ISLAM AND THE STATE IN INDONESIA:

Munawir Sjadzali and the Development of a New Theological Underpinning of Political Islam

Bahtiar Effendy 


\section{STIDLA ISLAMIKL}

Indonesian Journal for Islamic Studies

Volume 2, Number 2, 1995

EDTTORIAL BOARD:

Harun Nasution

Mastubu

M. Quraisb Sbibab

A. Aziz Dablan

M. Satria Effendi

Nabilab Lubis

M. Yunan Yusuf

Komaruddin Hidayat

M. Din Syamsuddin

Muslim Nasution

Wabib $\mathrm{Mu}$ tbi

EDITOR IN CHIEF:

Azyumardi Azra

EDTTORS:

Saiful Muzani

Hendro Prasetyo

Joban H. Metileman

Nurul Fajri

Badri Yatim

ASSISTANTS TO THE EDITOR:

Arif Subban

Mucblis Ainurrafik

ENGLSH LANGLAGE ADVISOR:

Judith M. Dent

ARABIC LANGUAGE ADVISOR:

M. Fuad Fachruddin

COVER DESIGNER:

S. Prinka

STUDIA ISLAMIKA (ISSN 0215-0492) is a journal published quarterly by the Institut Agama Islam Negeri (IAIN, The State Institute for Islamic Studies) Syarif Hidayatullah, Jakarta, (STT DEPPEN No. 129/SK/DITJEN/PPG/STT/1976) and sponsored by the Department of Religious Affairs of the Republic of Indonesia. It specializes in Indonesian Islamic studies, and is intended to communicate original researches and current issues on the subject. This journal warmly welcomes contributions from scholars of related disciplines.

All articles published do not necessarily represent the views of the journal, or other institutions to which it is affiliated. They are solely the views of the authors. 


\section{Islam and the State in Indonesia: Munawir Sjadzali and the Development of a New Theological Underpinning of Political Islam ${ }^{1}$}

Abstraksi: Hubungan Islam dan negara merupakan salah satu persoalan yang rumit di Indonesia. Sejak awal kemerdekaan, perdebatan mengenai Islam dan negara telab banyak mewarnai perjalanan sejarab bangsa ini. Sebagian Muslim Indonesia berkeinginan kuat untuk menjadikan Islam sebagai agama dan ideologi negara. Keinginan ini berulangkali diupayakan, namun selalu menemui kegagalan. Baik kalangan non-Muslim maupun sebagian Muslim lainnya tidak menginginkan Islam dijadikan sebagai agama resmi negara maupun ideologi yang mendasari sistem negara. Sejarah membuktikan babwa pibak yang kedua selalu berhasil menangkal keinginan pibak pertama.

Meskipun demikian, bukan berartiperjuangan kalangan Muslim yang menginginkan Islam sebagai ideologi negara telab berbenti dengan kegagalan tersebut. Upaya ke arah itu tetap terus dijalankan oleh para tokob-tokob yang sejak awal menginginkan formalisasi Islam dalam sistem negara. Pada awal Orde Baru, beberapa pibak memperjuangkan untuk dipulibkannya partai-partai Islam yang dibubarkan pada masa pemerintaban presiden pertama Indonesia Sukarno. Mereka juga menginginkan diberlakukannya Piagam Jakarta yang jelas-jelas menjamin eksistensi Islam dalam negara.

Situasi seperti ini otomatis menciptakan citra tertentu tentang Islam dimata pemerintab yang tidak sependapat dengan kecenderungan mereka. Baik Soekarno (Orde Lama) maupun presiden kedua, Soebarto (Orde Baru), sedikit banyak menganggap Islam, kbususnya Islam politik, sebagai kekuatan yang dapat mengancam keberlangsungan negara Indonesia yang pluralistik. Maka ketika Soebarto memegang kekuasaan, ia melancarkan kebijakan yang membatasi gerak Islam politik. Ia memberlakukan ideologi negara Pancasila sebagai satu-satunya asas bagikebidupan politik dan bernegara. Ia juga tidak mengabulkan keinginan sebagian Muslim 
untuk merehabilitasi partai-partai Islam lama. Dengan demikian, aktivitas politik yang mengatasnamakan Islam semakin sempit ruang geraknya dalam percaturan politik nasional.

Keinginan menjadikan Islam sebagai ideologi dan sistem negara banyak didasarkan pada anggapan babwa Islam tidak sekedar agama. Khusus dalam bubungannya dengan politik, slogan yang didengungkan adalab inna al-Islâm al-dîn wa al-dawlah, sesunggubnya Islam adalab agama dan negara. Maka kalangan yang meyakini pandangan ini cenderung berpendapat babwa Islam memiliki preferensi sistem politik yang bersifat definitif.

Jika pada masa Orde Lama antagonisme tentang bubungan antara Islam dan negara begitu kuat, di masa Orde Baru muncul pemikiran lain yang mencoba mencaripenyelesaian atas masalah tersebut. Para tokob gerakan pemikiran ini umumnya kalangan muda aktivis Himpunan Mabasiswa Islam (HMI). Salab satu figur utama darikelompok ini adalab Nurcholish Madjid, yang pernab menjadiketua HMI selama dua periode.

Madjid memunculkan pemikiran teologis yang dampaknya sangat kuat bagi gerakan serupa yang datang kemudian. Ia berangkat dari pemabaman radikal tentang doktrin tawhîd yang menjadi dasar bangunan Islam. Inti pemikirannya berkisar pada upaya desakralisasi terhadap segala sesuatu yang bersifat profan. Partai politik, misalnya, yang jelas berada pada wilayah profan, menjadi salah satu bidang yang terkena program desakralisasi. Madjid berusaba mengoreksi kecenderungan kalangan Muslim yang pada masa sebelumnya cenderung melibat persoalan politik, kbususnya partai Islam, sebagai masalah keagamaan.

Munawir Sjadzali, yang pernab menjadi Menteri Agama selama dua periode (1983-1993), termasuk tokob penting yang menggulirkan program pembabaruan pemikiran dalam Islam. Munawir dapat dikatakan sebagai pendatang baru bila dibandingkan dengan tokob-tokob muda seperti Nurcholish Madjid dan kawan-kawannya. Namun demikian, ia dapat disebut sebagai pemikir yang menyumbangkan rumusan "jalan tengab" mengenai bubungan Islam-negara. Munawir menolak kalangan yang memandang Islam memiliki preferensi sistem politik. Namun, ia juga menolak anggapan babwa Islam tidak memiliki kaitan sama sekali dengan persoalan kenegaraan. Menurutnya, Islam tetap menyediakan prinsip-prinsip umum yang dapat dipakai sebagai aspirasi dalam penyelenggaraan kekuasaan. Keterkaitan Islam dalam negara terjadi pada level substansi ajaran yang berfungsi sebagai prinsip-prinsip umum. 


\section{الإسبلام والدولة فلم إندونيسيا:}

\section{منور شاذلى و تجديد الفكرة الدينية للسياسة الإسلامية}

تعتبر العلاقة بين الإسلام والدولة بإندونيسيا مـن المشـاكل المعقدة. فأصبعح البهدال

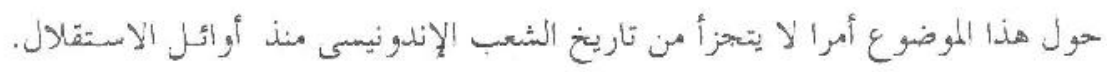

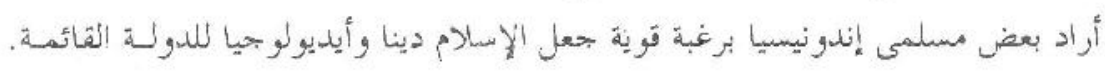

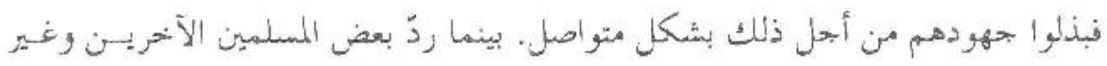

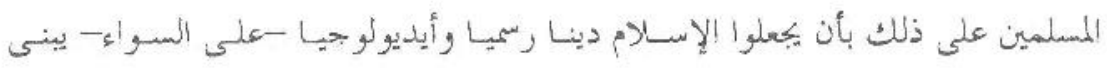

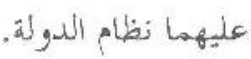

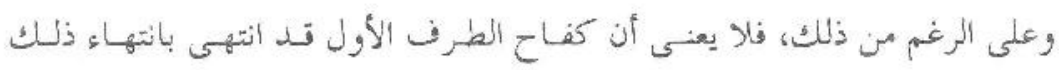

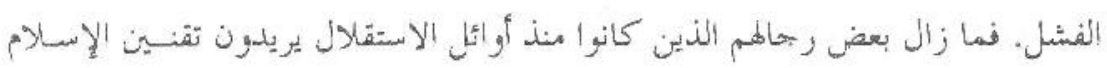

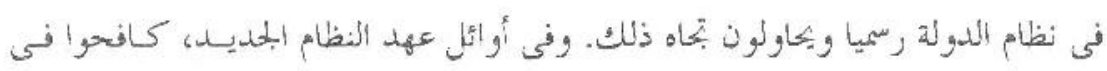

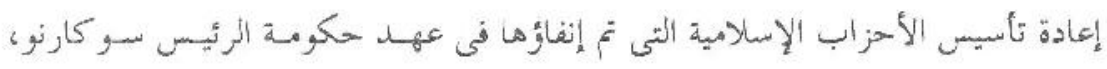

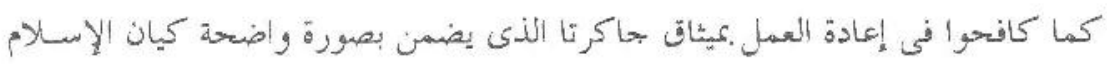
في نفابام المدولة.

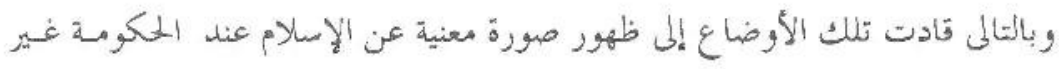

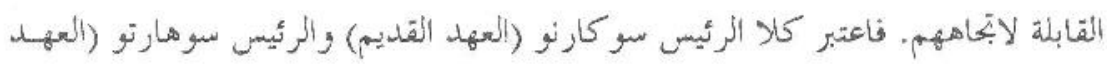

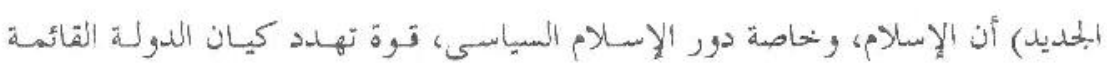

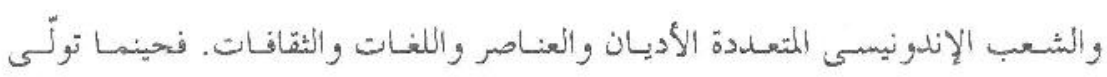

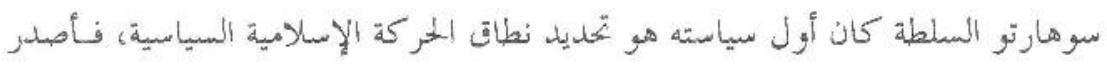


قرارا يجعل البانتشاسيلا (المبادئ الخمسة) أيديولوجية للدولة وأساسها الوحيد الذى تقوم عليه الحياة السياسية والوطنية. وإذا كانت دائرة الخُصومة بشأن العلاقة بين الإسلام والدولة في عهد النظام القديسم

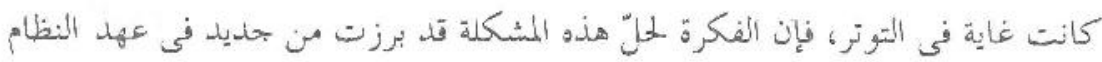

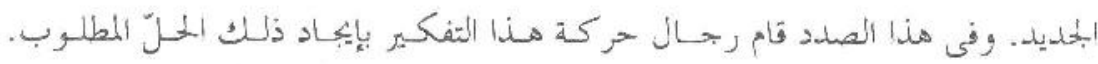

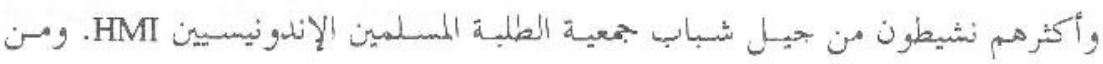

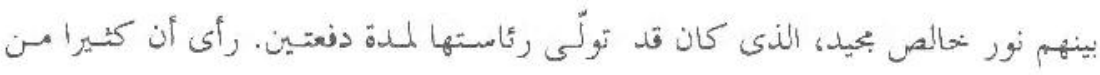

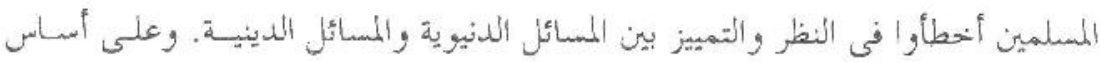

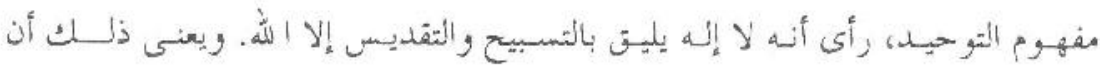

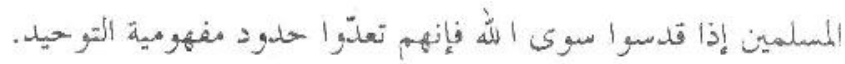

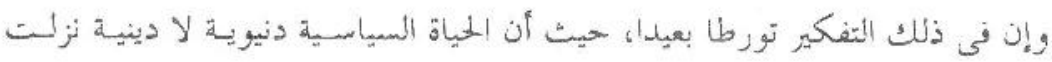

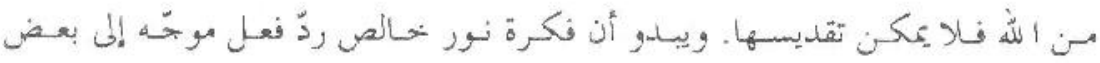

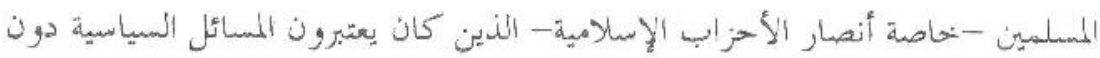

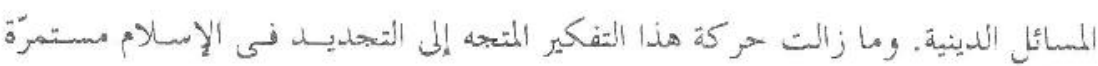
وتمبورة عمهورا بعد ذلنك.

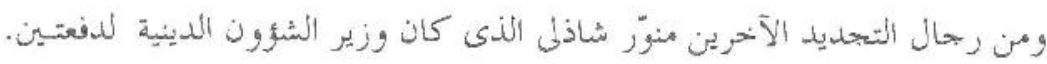

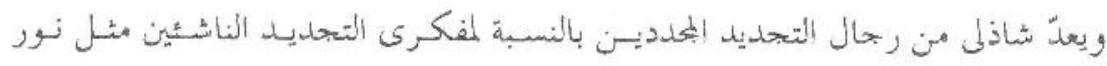

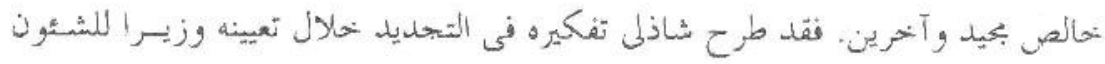

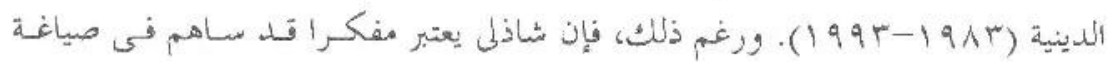

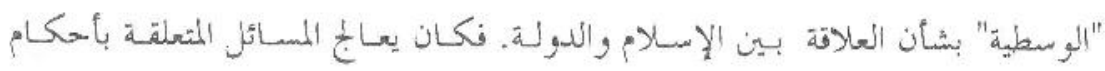

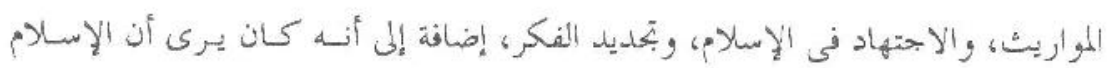

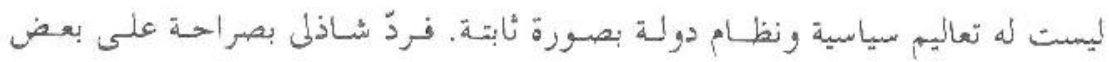

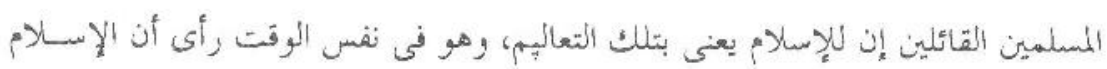

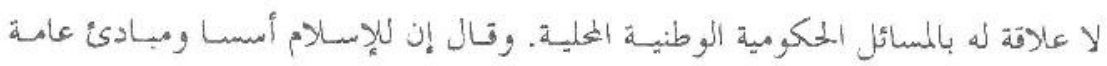
تصلح كشعار لاقامة نظام السلطة و الدولة. 
If Islam is to be preserved as a social and political force in Indonesia, someone will have to serve as cultural mediator between that Islam and the new national culture of Indonesia.

Leonard Binder ${ }^{2}$

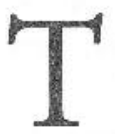
he relationship between Islam and the state has long been a delicate and controversial subject in the Muslim world. Since the unravelling of Western colonialism in the mid-twentieth century, Muslim countries such as Turkey, Egypt, the Sudan, Morocco, Pakistan, Malaysia, or Algeria have experienced difficulties in the attempt to establish a viable synthesis between Islamic political movements and ideas and the state in their respective localities. In these countries, the political relationship between Islam and the state has been characterized by severe tensions, if not hostilities. Given the preponderant position of Islam in these regions, that is as the religion of the majority of their inhabitants, this is indeed a puzzling reality. As such it has caused many students of political Islam to raise the question of whether Islam is actually compatible with a modern political system, in which the idea of the nation-state serves as a major ingredient. ${ }^{3}$

In Indonesia, Islam has long been at an impasse in terms of its political relationship with the state. The governments of both Presidents Soekarno and Soeharto have regarded political parties based on Islam as potential contenders for power capable of undermining the nationalist basis of the state. Primarily because of this, for more than four decades they have worked to contain and "domesticate" Islamic parties. As a result, not only did leaders and activists of political Islam fail to make Islam the state ideology and religion in 1945 (the eve of Indonesia's independence) and again in the late 1950s (during the Constituent Assembly's debate over Indonesia's constitutional future), but they also found themselves repeatedly labelled as "minorities" or "outsiders." In short, as some have suggested, political Islam has been constitutionally, physically, electorally, bureaucratically, and symbolically defeated. ${ }^{5}$ Most distressing, political Islam has frequently been a target of distrust, suspected as opposing the state ideology of Pancasila.

For their part, politically active Muslims have regarded the state with suspicion. In spite of the willingness of the state to recognize 
and assist Muslims in the practice of their religious rituals, they consider the state as maneuvering to dethrone the political significance of Islam and embrace the idea of a secular polity. In fact, this situation has often been perceived as an indication that the state is applying a dual policy on Islam. That is, while allowing the ritual dimension of Islam to flourish, it does not provide opportunities for political Islam to develop. ${ }^{6}$ In this respect, suffice to say that a mutual suspicion between Islam and the state occurs in a country in which the majority of its populations is Muslim. ${ }^{7}$

It is this kind of mutual political antagonism which the new Islamic intellectualism, emerging in the early 1970s, intended to remedy. Operating with three different modes of thought - theological/ religious renewal, political/bureaucratic reform and social transformation - its primary purpose has been to develop a new format of political Islam which is perceived to be congruent with the construction of Indonesia's unitary nation-state.

This essay does not intend to explore a possible answer to the puzzle raised above. Rather, within the framework of the state-Islam relationship, it intends to assess the role of Munawir Sjadzali, a proponent of the Islamic reactualization agenda, in the discourse of Indonesia's new Islamic intellectualism. Being one of the most notable contributors, Munawir has been extremely instrumental in shaping and developing the course of the archipelago's new Islamic intellectualism. Given the framework set up in this essay, that is the political relationship between Islam and the state, attention will primarily be focused on (1) Munawir's religious ideas and (2) how those ideas have shaped his political thoughts, especially with regard to the development of a new theological underpinning of political Islam.

\section{Reactualizing Islam:}

\section{A Response to Islamic Legalism and Formalism}

From the perspective of the new Islamic intellectualism, the problems confronting political Islam do not merely concern practical issues. In spite of the fact that the problems emerged rather exclusively in the form of a chronicle of political havoc, there has been a widely held belief that the crux of the matter went beyond these practical domains. Observing the intellectual discourse of Indonesia's Islamic political thinking, particularly with regard to ideas concerning the proper relationship between Islam and the state, many have concluded 
that the problems are related to, if not rooted in, the theological or philosophical dimensions of political Islam. In their view, these theological or philosophical underpinnings - which in themselves were products of Muslims' understanding of their religious doctrines influenced and shaped the ideas and practices of political Muslims, particularly those of the earlier generation.

As Indonesia's post-colonial politics unfolded, it appeared that political Muslims experienced great difficulties in synthesizing their theological or philosophical foundations with the existing socio-cultural and political realities. This was particularly the case with regard to their attempt to formulate nationally acceptable linkages between Islam and the state. Numerous political episodes have indicated that efforts to establish a formalistic and legalistic connection between Islam and the country's political system ended up with an impasse, sharp ideological and political animosity, or violence.

As a result of this difficult and uneasy conversation, the political ideas and practices of the earlier generation of political Muslims grew to become a seemingly unbridgeable gap between them and their nationalist counterparts. Even though the latter included a substantial number of Muslims, they have never been in favor of the idea of a formalistic and legalistic bond between Islam and the state. Throughout the course of Indonesia's modern political history, they have rejected the notion of an Islamic state, or Islam as the ideological basis of the state. This ideological political conflict created hostilities among these different groups.

When the position of political Islam appeared to be worsening, particularly following the New Order's maneuver to restructure Indonesia's political format, many of its leaders became increasingly reactionary. In the opinion of some observers of Indonesian political Islam, this was a sign of the inability of Islamic political thinkers and activists to structure intelligent religio-political responses pertinent to these challenges. ${ }^{8}$ Therefore, despite the fact that their political agendas in the early years of the Soeharto government (i.e. pressing for the legalization of the Jakarta Charter, demanding the rehabilitation of the proscribed Masyumi, and striving for direct involvement of the former Masyumi leaders in the newly established Parmusi) were rejected by the New Order, defenders of the past format of political Islam remained virtually unchanged, making their orientation toward politics and religion practically rigid. Many have interpreted this per- 
sistently inflexible religio-political behavior as an indication of their inability to relinquish their formalistic and legalistic approach in politics. $^{9}$

There is no doubt that their resoluteness was deeply motivated. Put simply, it was based on religious belief derived chiefly from their understanding of the holistic nature of Islam. But, given the country's socio-religious heterogeneity, it was nonetheless not well conceived. Primarily because of this, in the view of some advocates of the new Islamic intellectualism, Islamic political elites - particularly their modernist wing - "suffered from inflexibility, almost dogmatism, in practical considerations." ${ }^{10}$ They questioned the soundness of the overall strategy, tactics, and goals of political Islam as defined by the older elites. In fact, many of them even directly challenged the notion of Islam as an ideology; or the idea that the state is an extension (or integral part) of Islam. "Although Islam, as a religion, does contain socio-political teachings," argued M. Dawam Rahardjo, an important figure in the new Islamic intellectual movement, "it is not in itself an ideology." Thus, "[an] 'Islamic Ideology' does not exist." ${ }^{12}$ In the meantime, in attempts to relate Islam and the state more appropriately, Djohan Effendi, another notable participant in the new Islamic intellectualism, as recalled by Ahmad Wahib, on various occasions suggested that the prophet Muhammad himself did not actually proclaim an Islamic state. ${ }^{13}$

In the light of these religio-political and intellectual developments, advocates of the new Islamic intellectualism believe that the heart of the problem lies in a specific mode of theological expression common among many Muslim political thinkers and activists. At some point in their historical experiences, the perceptions of the older leaders and activists of political Islam fixed on a religious view of worldly affairs (i.e. politics) that was too formalistic, legalistic or scripturalistic in orientation. In the opinion of the emerging defenders of the new Islamic intellectualism, unless such a mode of theological formulation is transformed or at least becomes more flexible and adaptive, it seems unlikely that a viable synthesis between Islam and the state can be established.

Against this background, the new wave of Islamic intellectualism has called for the refurbishment of Islamic thought and the rejuvenation of religious understanding. In the context of modern Indonesian Islam this is not an entirely novel agenda. Some of the basic proposi- 
tions resemble concerns expressed by Soekarno who, in the 1930s, voiced the opinion that Indonesian Muslims should rediscover the "api Islam" (the "fire of Islam") rather than simply grasping the messages of Islam in its literal or textual sense. ${ }^{14}$

What the proponents of this new Islamic intellectualism want to convey with these reinvigorating religio-political themes, although often misunderstood by its critics, is not a proposal to revise the doctrines of Islam. Like all other Muslims, they believe that Islam is permanent. But, they are also convinced that Muslims' understanding or interpretation of the Qur'ân and Sunnah, the two primary sources of Islamic teachings, is subject to change. Accordingly, comparable to the profound concerns of many other past prominent Islamic reformers and thinkers (e.g. Jamâl al-Dîn al-Afghânî, Muhammad Abduh, Rashî̀ Ridâ, etc.) whose influences are still palpable in the Muslim world, they simply want to urge their fellow Muslims to rethink their understanding and interpretation of Islam as societal circumstances warrant. ${ }^{15}$

By doing so, it is expected that Muslims' comprehension of their religious messages will not stagnate. More importantly, reflecting the belief that Islam is timeless and universal (al-Islâm sâlih li kulli zaman wa makân), ${ }^{16}$ Muslims should not lose their grip on the demands of modernity. Rather, they should be able to conduct a productive and intelligent dialogue between the universality of Islamic teachings and the necessity of - in this particular case - Indonesia's spatio-temporal particularities. Included in this sociological framework are the heterogeneous characteristics of the archipelago's socio-religious structures as well as its political orientations.

From the late 1960 s to the mid-1970s, this new Islamic intellectualism was particularly, though not exclusively, strong among some activists in some Islamic student organizations such as Himpunan Mahasiswa Islam (HMI, Islamic University Student Association). Being one of the most renowned Islamic student associations in the country, HMI was probably the best organization to be affiliated with in order to cultivate familiarity with numerous important issues pertinent to Muslims as well as to Indonesian society at large. ${ }^{17}$ Though this agenda for renewal was never adopted as an official policy of the organization - thanks to the differing opinions among the organization's members concerning the nature and substance of the reform movement on the one hand, and the history of political Islam 
on the other - many of its influential leaders and activists became the intellectual actors of the reform movement. ${ }^{18}$

In Yogyakarta, where HMI was formed in 1947, this theological renewal was centered around the younger figures such as Djohan Effendi, Manshur Hamid, Ahmad Wahib and to some extent M. Dawam Rahardjo. These individuals, in addition to being HMI activists, were also regular participants of the Limited Group (1967-1971). ${ }^{19}$ As reflected in Ahmad Wahib's controversial diary, Pergolakan Pemikiran Islam, this was an open discussion forum primarily focused on religious, social, cultural and political affairs. ${ }^{20}$ Being liberal as it was, the Limited Group provided ample opportunities for its members to express their ideas without fear of being construed as stepping beyond the boundary of religious or theological appropriateness. ${ }^{21}$ Throughout its existence, this forum was under the direction of $\mathrm{A}$. Mukti Ali, a professor in the field of comparative study of religion at Yogyakarta's Institut Agama Islam Negeri (IAIN, State Institute for Islamic Studies), who was also Minister of Religion from 1971-1978, ${ }^{22}$

Through lengthy and intense discussions, conducted both within HMI circles and in the Limited Group, they came to a number of theologically-focused conclusions. Though not claiming originality, given that many other individuals also shared similar findings, they nonetheless reasserted several important propositions and packaged these into a new religio-political perspective on the relationship between Islam and the state.

Firstly, in their view there is no clear-cut evidence that the Qur'ân and Sunnah oblige Muslims to establish an Islamic state. According to their observations, Muhammad's political experimentation did not include the proclamation of an Islamic state. Because of this, they rejected the political agenda of earlier leaders and activists of political Islam that seem to demand the formation of an Islamic state or a state based on Islamic ideology. ${ }^{23}$

Secondly, they recognized that Islam does contain a set of sociopolitical principles. Even so, they hold the view that Islam is not an ideology. Therefore, in their opinion, an Islamic ideology does not exist. ${ }^{24}$ In fact, according to some of them, the ideologization of Islam can be considered to be a reductionism of Islam. ${ }^{25}$

Thirdly, since Islam is conceived as timeless and universal, Muslims' understanding of it should not be confined to its formal and legal sense, particularly that drawn from a specific time or place. In- 
stead, it should be based on thorough interpretations which apply its textual or doctrinal denotation to the contemporary situation and context. This viewpoint in turn, necessitates the transformation of Islam into a contemporary set of principles and practices. ${ }^{26}$

Fourthly, they strongly believe that only Allah possesses the absolute truth. Thus, it is virtually impossible for mankind to grasp the absolute reality of Islam. In their judgement, Muslims' comprehension of their religious doctrines remains essentially relative in value and therefore subject to change. Given this polyinterpretability of Islam on the one hand, and the fact that Islam recognizes no religious priesthood (lâ rabbaniyyab fi al-Islâm) on the other, there should be no individuals who can claim that his or her understanding of Islam is truer and more authoritative than that of others. Accordingly, it is imperative for Muslims to foster religious tolerance, internally as well as externally. ${ }^{27}$

With these fundamental premises in mind, advocates of the new Islamic intellectualism have campaigned for the more substantive less symbolical - nature of the Islamic political struggle, in which programs rather than partisan ideology serve as the primary orientation. Shifting their focus away from structure and attempting to end the hostility between political Islam and the state, they see no reason not to accept the current form of the state. In fact, they restated the position of HMI and other Islamic organizations which, as early as 1969, suggested that Pancasila be accepted as their political ideal. Finally, they assert that Muslims should make their primary commitment to Islam (i.e. Islamic values) and not to institutions or organizations (i.e. Islamic parties). ${ }^{28}$

The watershed of this theological renewal movement, however, originated with Nurcholish Madjid, a graduate from IAIN Jakarta, who for two consecutive periods served as the national chairman of HMI (1966-1969 and 1969-1971). On 2 January 1970, he delivered a speech to a gathering of four Islamic organizations: HMI, Pelajar Islam Indonesia (PII, Indonesian Islamic Student Association), Gerakan Pemuda Islam Indonesia (GPII, Indonesian Islamic Student Movement), and Persatuan Sarjana Muslim Indonesia (Persami, Indonesian Muslim Scholar Association). ${ }^{29}$ In his paper, "Keharusan Pembaharuan Pemikiran Islam dan Masalah Integrasi Ummat" (The Necessity of Renewal of Islamic Thought and the Problem of Integration of the Islamic Community), Nurcholish offered the straightforward obser- 
vation that Indonesian Muslims suffered from stagnation in religious thinking and had lost the "psychological striking force" in their struggle. ${ }^{30}$ An important indication of this intellectually-disarticulated Indonesian Islam, as observed by Nurcholish, was the inability of the vast majority of Muslims to differentiate values which are transcendental from those which are temporal. In fact, he further pointed out that the hierarchy of values is often the reverse; transcendental values are conceived to be temporal and vice versa. Everything is likely to be perceived as transcendental and, therefore, without exception, valued as divine. As a result of this mode of religiosity, "Islam is [viewed as] equal in value to tradition; and becoming Islamic is comparable to being traditionalist." 31

Reform of this situation is possible provided that Muslims are prepared to undertake a path of renewal - even if the choice is at the expense of the integration of the ummab (Islamic community). To undergo this religious renewal he suggested that Muslims liberate themselves from the tendency to transcend values, which are supposedly profane, into the domain of divinity and to initiate creative thinking relevant to the demands of the modern age. This endeavor can only be realized if Muslims enjoy some degree of confidence to allow ideas to be expressed and communicated freely. But more importantly, Muslims need to be open minded, willing to accept and absorb any ideas, regardless of their origins, provided they objectively speak of the truth. ${ }^{32}$

Nurcholish's fundamental viewpoints where derived from his radical understanding of two basic principles in Islam: (1) the concept of al-tawhid (oneness of God); and (2) the notion that men are the vicegerents of God (kbalîfab al-Allâh fî al-ard). From these two principles he formulated his theological premises which suggest that only Allah possesses absolute transcendency and divinity. As a consequence of their acceptance of this monotheist principle, Muslims should naturally perceive the world and its temporal affairs (social, cultural or political) as they are. Viewing the world and its objects in a sacred or transcendental manner can be considered to be theologically contradictory to the very notion of Islamic monotheism. ${ }^{33}$

The implication of such theological pronouncements, in Nurcholish's view, is that there is nothing sacred about the matter of an Islamic state, Islamic political parties or an Islamic ideology. ${ }^{34} \mathrm{Ac}-$ cordingly, Muslims - again primarily because of the logical conse- 
quences of their adherence to the principle of al-tawbid - should be able to "secularize" or "desacralize" their perceptions of these worldly issues. In the light of this, he introduced the phrase: "Islam Yes, Partai Islam No (Islam Yes, Islamic Party No). ${ }^{35}$ With such jargon, among other things, he encouraged his fellow Muslims to direct their commitment to Islamic values and not to institutions, even those of Islamic origin such as Islamic parties.

In a situation such as this, Munawir Sjadzali emerges, contributing to the form and substance of the new Islamic intellectualism and activism. Complementing his fellow reformers, this long time senior officer in the Department of Foreign Affairs who, for two consecutive periods (1983-1993), served as the Minister of Religion, suggests the necessity for the reactualization of Islamic teachings. His familiarity with Islamic scholarship went back to his teenage years when he was a student at Mambaul Ulum, a noted pesantren in Solo, Central Java. Though later on he completed his graduate work at Georgetown University's Department of Political Science where he wrote an M.A. Thesis on "Indonesia's Muslim Parties and their Political Concept" (1959), his interest in Islamic subjects never ceased. In this respect, he is actually an autodidact, taking full advantage of his easy access to Islamic classical as well as contemporary literatures. He collected many works while he was ambassador to the United Arab Emirates from 1976-1980. ${ }^{36}$

Given the time of his rise as an advocate of the new Islamic intellectualism, it can be suggested that in the reform movement Munawir is actually a late-comer. Unlike his younger counterparts, who began to take up the renewal agenda in the 1970 s, his ideas concerning religious reactualization were virtually unknown prior to his appointment as the Minister of Religion. His long years of service in the Department of Foreign Affairs (1950s-1983) had prevented him from taking an active role in the initial discourse of the new Islamic intellectualism. But it was a blessing in disguise. The disengagement, as he himself recognized, provided him with ample opportunities to observe, and think about, Indonesian Islam more objectively. ${ }^{37}$

The central point of his message was to encourage Muslims to take up religious ijtihâd (deliberate independent judgment) honestly, to make Islam more responsive to the needs of Indonesia's local and temporal circumstances.$^{38}$ In this regard, one of his most frequently discussed topics is the principle of Islamic inheritance. On this matter 
the Qur'ân stipulates that sons inherit twice as much as daughters. Drawing, among others, from his own personal experiences, he concludes that in some circumstances this particular regulation appears to be contradictory to the very notion of justice. According to Munawir, many 'ulama' have realized this issue, but have been unwilling to resolve the matter conclusively. Instead, like many other Muslims, they prefer to take preemptive moves by substantially reducing the amount of the assets to be inherited. By and large, these practices are carried out in a manner where by properties are distributed ( $b i b b a b)$ to their children, on their own terms, before their deaths. ${ }^{39}$

The significance of Munawir's reactualization agenda lies beyond the rhetoric of the inheritance issue. A closer look at the framework of his theological thought seems to suggest that he is inclined to argue that there are some Qur'ânic stipulations - associated in particular with societal, not ritual, affairs - which are no longer compatible with the demands of the present era (e.g. inheritance law, slavery, etc.). In these cases, he relies in the main, but not exclusively, on the practices and examples of the second Caliph, 'Umar ibn al-Khattâb. According to Munawir, due to the changing social circumstances, 'Umar applied out policies which did not fully comply with the stipulations laid out by the Qur'ân and the traditions of the Prophet. Most notable was his policy concerning the distribution of the spoils of war.

Inspired by the courageous and honest ijtihâd of 'Umar, Munawir suggests that there should be aggressive and candid measures to deal with Islamic doctrines. Believing in the dynamism and vitality of Islamic law, he proposes that Muslims should undertake a reactualization agenda to make Islam more suitable to Indonesia's own local and temporal particularities. ${ }^{40}$

\section{The Implication of Islamic Reactualization:}

His Contribution to the Development of A New Theological Underpinning of Islam

Given Munawir's ideas, especially the way he perceives Islamic teachings as well as the whole construct of ijtibâd, there are at least three major implications with regard to his Islamic reactualization agenda. His main thoughts have actually called for (1) the reformulation of a new theological underpinning of political Islam; (2) the re- 
definition of the socio-political objectives of Islam; and (3) the reassessment of the political approach of Islam. However, considering the nature of his reactualization agenda, which is more religious or "theological" in orientation, the discussion will be limited to the extent that his religio-political ideas contributed to the development of a new theological underpinning of political Islam.

Briefly, the nucleus of the theological underpinning of political Islam of any stream is a belief in the holistic nature of Islam. ${ }^{41}$ This religious premise is perceived to be an indication that Islam provides knowledge about every aspect of life. In fact, this particular viewpoint has become the chief basis for an understanding that Islam recognizes no separation between religion and the state, between the transcendental and the temporal.

In the past, Indonesia's political Muslims has used this tenet to establish and further their social and political agendas. This included a perception that Islam furnishes its adherents with a full-fledged concept of the state or system of governing. In addition, some of them even maintained that the state is in fact an integral part, or extension, of Islam. This is a religio-political stance which, in some quarters of the Islamic world, is popularly phrased as inna al-Islâm al-din wa aldawlab -that Islam is both a religion and the state. From this perspective, they insisted that it was appropriate for them to propose that Islam be adopted as the ideological basis of the state. ${ }^{42}$

Proponents of the new Islamic intellectualism also earnestly believe in the notion of Islamic holism. Nonetheless, they reject the conclusion of the earlier generation of Islamic thinkers and activists, drawn from such a religious precept. They assert that the holistic nature of Islam does not necessarily require a mixture of the divine (i.e. Islamic values) and the profane (i.e. state, political organization, ideology, etc.). Nor does it imply an understanding that these two different realms should be placed on the same level. In their view, though Islam does not acknowledge the notion of partition between these two domains, they can and in fact must be differentiated. Placing these two domains as parallel will only lead to confusion in the structure and hierarchy of Islamic values (such as portraying the form of state, ideology or political party as sacred objects). This in turn

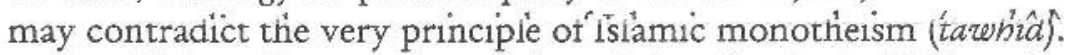

In addition, they are also of the opinion that in itself Islam does not actually regulate every aspect of life. Instead, they believe that as 
far as the societal (not ritual) doctrines of Islam are concerned, it appears that Islam only provides moral values which serve as basic and general guidelines for human life.

Complementary to such a line of thought, writing in the late 1950s for his M.A. thesis, Munawir indirectly suggests that there is no such thing as an Islamic political concept. ${ }^{43}$ When he actively participates in the discourse of the new Islamic intellectualism, especially in the early 1980 s and 1990s, he not only maintains such a religio-political stance, but also developed the idea into a paradigmatic proposition. The hallmark of his religio-political thoughts is manifested in the publication of his Islam dan Tata Negara (Islam and the Administration of the State) in $1990.4^{44}$

In his work, he critically examines the stipulations of the Qur'ân and Sunnah concerning the position of Islam vis-a-vis the state in particular and politics in general. Through such an intellectual venture (doctrinal as well as empirical), he tries to investigate and determine whether or not Islam does indeed lay down explicit concepts (or simply a set of general principles) of the state, politics and a system of governing. In addition, given Islam's centuries-long encounter with those issues, both in terms of thoughts and actions, he also revisits the theoretical statements of a number of prominent classical (e.g. Ibn Abî Râbî̀ Al-Farâbî, Al-Mawardî, Al-Ghazâlî, Ibn Taymiyyah, Ibn Khaldûn) as well as modern (e.g. Al-Afghânî, Muhammad Abduh, Rashîd Ridha, 'Alî Abd al-Râziq, Abu al-A 'lâ al-Mawdûdi, Muhammad Husein Haykal) Islamic thinkers on the specific subject of the political relationship between Islam and the state.

In this intellectual quest, he finds no clear indications that Islam has a profound interest in regulating issues pertinent to the affairs of the state. From the Qur'ân, he sees no doctrines which specifically discuss the issue. In fact, given the significance of the matter, it is astonishing to learn that the term "state" (dawlab) does not even appear in the Qur'ân. Furthermore, to support the view that the question of an Islamic state (dawlah Islâmiyyah) is in fact a modern phenomenon - a product of the encounter of the Muslim world with Western colonialism, as some have suggested - he is of the opinion that a formal declaration of an Islamic state had never actually been made during the period of classical or medieval Islam..$^{45}$

Munawir's intellectual inquiry also finds no evidence that the traditions of Muhammad (sunnab) deal with the question of state or poli- 
tics in a more comprehensive fashion. In his view, the Sunnah like the Qur'ân, does not set forth a detailed model of how a state should actually be organized. In fact, in his opinion, Muhammad himself did not even provide a clear indication that what he created in Medina was actually a political institution which could be labelled as a state.

As expressed in his writings and interview statements, this viewpoint is partly drawn from the fact that a fixed mechanism for leadership succession and transfer of power/authority was absent in the early days of Islamic political history. Both theoretical (doctrinal) as well as empirical (historical) Islam indicate that the Prophet Muhammad did not formulate such a necessary procedure for the management of the state. On these particular issues (i.e. leadership succession and transfer of power/authority), the only recognized mechanism (in fact, it had become a kind of rule of thumb) was simply an obligation to apply the principle of syûrâ (consultation)..$^{46}$

Like many other proponents of Islamic intellectualism, especially those whose main concern is religious renewal, Munawir believes that there is no question concerning the applicability of the principle of syûrâ in the process of leadership succession and transfer of power/ authority. However, it is important to note that the practices of leadership succession - especially in the early period of Islam - varied from time to time. During the time of Muhammad, at least according to Sunni historical accounts, ${ }^{47}$ there was a widely held belief that he did not select a political successor. Abu Bakr, one of his closest companions, became the first Caliph through a limited election; 'Umar ibn al-Khattâb, the second Caliph, was appointed by Abu Bakr to succeed him; Uthmân ibn 'Affân was elevated to the office of the caliphate, to become the third Caliph, by a committee formed under the executive order of Umar; and 'Alî ibn Abî Tâlib became the fourth Caliph via a different form of election. ${ }^{48}$

Despite the lack of a clear conceptual construct, Munawir finds that both the Qur'ân and Sunnah do provide a set of ethical principles relevant to administering the state and its governing mechanism. He points out that the Qur'ân repeatedly mentions the normative ideas of consultation (syûrâ), justice ('adl) and egalitarianism (musâwab). According to him, these were the very principles which were applied and demonstrated vigorously in the political traditions of early Islam, particularly during Muhammad's time.

The best expression of this set of ethical values (i.e. the principles 
of consultation, justice and egalitarianism) was Muhammad's Constitution of Medina (Mîthâq al-Madînab). This Constitution, as many have perceived it, was the governing formula which regulated the socio-political relationships among members of the Medina community. At which time, this single political community, described by Muhammad as an ummah, constituted a number of different religious groups such as: Muslims, Jews and tribal-pagans. ${ }^{49}$

Some have considered the political tenets expressed in the Constitution of Medina as a common platform which enabled the process of socio-political convergence to take place among the subjects of a political community with different religious backgrounds. Others recognize it as a political document which provides a basic model for the relationship between Islam and politics, and Islam and the state.

In spite of the variations in the perceptions of this Constitution, the significance of this political document rests primarily on its emphasis on the principles of justice, participation, consultation and egalitarianism. For Munawir, this perception is reinforced by the fact that, regardless of the majority position of Muslims in the composition of Medina's political community, this Constitution did not mention Islam as the formal religion of the state. In his Islam dan Tata Negara he wrote:

One thing which should be noted is that the Constitution of Medina, which is perceived by many students of politics as the constitution of the first Islamic state, did not mention [Islam as] the religion of the state. ${ }^{50}$

This point is important for Munawir because he considers reference to a certain religious belief as the religion of the state as a necessary condition for the existence of a theocratic state (negara agama). Therefore, in his view, the fact that the Constitution of Medina did not mention Islam as the religion of the state suggests that Muhammad did not actually call for the establishment of a theocratic state in which Islam would have served as its sole basis..$^{51}$

Based on this examination, it can be concluded that, for Munawir Islam does not have any particular conceptual or theoretical preferences concerning the nature or construct of the state and its system of governing. It can also be suggested that Islam does not specifically oblige its adherents to establish a state, let alone a theocratic one. In spite of the absence of a full-fledged concept of the state or politics in Islam, nonetheless Islam does possess a set of ethical values or politi- 
cal principles, such as justice, consultation and egalitarianism. It is the substantive implementation, as once demonstrated by the political practices of Muhammad, of these particular injunctions which is compulsory in Islam.

With these theologico-political perceptions, Munawir, like many other proponents of the new Islamic intellectualism and activism, is actually advancing a "middle way" of Islamic political theorizing. In this respect, he does not share the formalistic, legalistic or scripturalistic interpretation of Islamic holism, as articulated most notably by Abû al-A'lâ al-Mawdûdî. ${ }^{52}$ At the same time, he also rejects the secular version of 'Alî̀ Abd al-Râziq's political ideas, which suggests a complete partition between Islam and the affairs of the state. ${ }^{53}$

In the opinion of Munawir, these two differing theoretical models have major weaknesses. Mawdûdî's theoretical error lies primarily in his failure to recognize the fact that Islam does not actually offer a definite or fixed mechanism to regulate political succession or transfer of power/authority - an important element in the construction of a theory of the political administration of the state.

By contrast, the defect in 'Abd al-Râziq's political theory is his perception that the state, as a political instrument, should be separated from any religious (Islamic) stipulations. This idea not only denied any possible connection (linkage) between Islam and the state, but also rejected in toto the normative aspects of Islam in the sociopolitical processes and the governing mechanism of the state. ${ }^{54}$

Putting Munawir's religio-political ideas into the Indonesian context, it can be conveniently suggested that these theologically-driven political ideas have undoubtedly played decisive roles in shaping his perceptions of (1) the nature of Indonesia's nation state; and (2) the position of Pancasila as the national ideology of the state.

Given the character of their theological values on the one hand, and the makeup of Indonesia's socio-religious and cultural situation on the other, it is obvious that Munawir shares the notion of a "national unitary" construct of the state. Within these limits, he actually sees the current form and structure of the state as the best imaginable model. Therefore, he unequivocally supports and accepts it. Like many Muslim leaders such as those of the Nahdlatul Ulama, he shares the notion that the present ideological construct of the state should be regarded as the final goal for Indonesian Muslims. ${ }^{55}$

Apart from the aforementioned theological considerations, for 
Munawir there are a number of important factors which serve as the direct basis for his support of Indonesia's "national unitary" construct of the state. These include the facts that (1) the state not only guarantees freedom for Muslims to implement their religious teachings, but also facilitates them; (2) the majority of the archipelago's population is Muslim; and (3) the state constitution does not contradict (in fact to some extent even reflects) the substance of Islamic principles. ${ }^{56}$ Put together, these factors represent an undeniable reality that, simply by virtue of the fact that the majority of the country's inhabitants are Muslim, the basic contour of its governing principles are in tune with, if not in fact influenced by, Islamic values. Within this framework, at least theoretically, the state will not implement laws and policies which are in direct conflict with Islamic teachings.

This seems to be the case with the nature of Indonesia's nation state. In fact, in the view of Munawir, it is gradually evolving as a "religious state", that is a state which is concerned with the implementation and development of religious values, without having to become a "theocratic" state which is constitutionally based on certain formal religious institutions. ${ }^{57}$ In this context, religion (Islam) provides the spiritual, ethical and moral basis for Indonesia's national development..$^{58}$

At this stage, it is fair to say that the principal factor of his acceptance of Indonesia's nation-state boils down to the fact that the Indonesian state provides ample opportunities for Muslims to implement their religious teachings. To some extent, it has also been strengthened by his perception of Pancasila ideology and the 1945 constitution. In his opinion, both the ideological and constitutional foundations of the state are in accordance with the teachings of Islam. More especially, each of the five principles of Pancasila, in particular the notions of transcendental monotheism, consultation and social justice, are considered to reflect the substance of Islamic teachings.

\section{Conclusion}

Based on such a lengthy and critical discussion, it is fair to suggest that Munawir's religio-political thinking, expressed in part through his Islamic reactualization agenda, has contributed greatly to the development of a new political meaning for Islam. As has been suggested, in this particular framework substance - rather than formality or legality - becomes an "imperative demand," religiously as well 
as sociologically. Accordingly, it can be said that the kind of theological or philosophical underpinning of political Islam which Munawir has been trying to redefine and shape can be labeled as substantialism. In this conception, Islam in politics is no longer based on scripture focused on ideological symbolism. Instead, congruent with the increasing exposure of Muslim youth (particularly those who have some sort of cultural or emotional linkage with Indonesia's earlier Islamic political movement) to modern tertiary education and to economic development, the expression of political Islam is carried out in a less symbolic or ideological fashion. In this model, the substantive values of political Islam identified earlier as justice, consultation and egalitarianism, serve as its core orientation.

\section{Footnotes}

1. A large proportion of the ideas developed in this essay originate from my Ph.D. dissertation "Islam and the State: the Transformation of Islamic Political Ideas and Practices in Indonesia," Ohio State University, 1994.

2. Leonard Binder, "Islamic Tradition and Politics: The Kijaji and the Alim," A commentary on Clifford Geertz's "The Javanese Kijaji: The Changing Role of A Cultural Broker," Comparative Studies in Society and History, Vol. 2, October 1959-July 1960, p. 256.

3. See, Leonard Binder, Religion and Politics in Pakistan (Berkeley and Los Angeles: University of California Press, 1963); Mohammed Ayoob (ed.), The Politics of Islamic Reassertion (London: Croom Helm, 1981); James P. Piscatori (ed.), Islam in the Political Process (Cambridge: Cambridge University Press, 1983); Fred Halliday and Hamzah Alavi (eds.), State and Ideology in the Middle East and Paki. stan (New York: Monthly Review Press, 1988); R. Hrair Dekmejian, Islam in Revolution: Fundamentalism in the Arab World (Syracuse: Syracuse University Press, 1985); Nazih Ayubi, Political Islam: religion and Politics in the Arab World (London and New York: Routledge, 1991).

4. See, Ruth McVey, "Faith as the Outsider: Islam in Indonesian Politics," James P. Piscatori (ed.), Islam in the Political Process, pp. 199-225; W.F. Wertheim, "Indonesian Muslims Under Sukarno and Suharto: Majority with Minority Mentality," Studies on Indonesian Islam (Townsville: Occasional Paper No. 19, Centre for Southeast Asian Studies, James Cook University of North Queensland, 1986).

5. See, Donald K. Emmerson, "Islam and Regime in Indonesia: Who's Coopting Whom?" A paper delivered at the annual meeting of the American Political Science Association, Atlanta, Georgia, USA, 31 August 1989.

6. This approach is widely perceived as the legacy of the Dutch colonial policy on Islam, formulated by its chief architect Snouck Hurgronje. See, Harry J. Benda, The Crescent and the Rising Sun: Indonesian Islam Under the Japanese Occupation 1942-1945 (The Hague and Bandung: W. van Hoeve Ltd., 1958).

7. See, Robert Jay, Religion and Politics in Rural Central Java (New Haven: South- 
east Asia Studies, Yale University, 1963); B.J. Boland, The Struggle of Islam in Modern Indonesia (The Hague: Martinus Nijhoff, 1971).

8. See, Allan Samson "Islam and Politics in Indonesia," Ph.D. Dissertation, University of California, 1972.

9. For a further analysis on this issue, see Allan Samson, "Islam in Indonesian Politics," Asian Survey, No. 12, Vol. VII, December 1968, pp. 1001-1017; See also his "Indonesian Islam Since the New Order," Ahmad Ibrahim, Sharon Siddique, Yasmin Hussain (eds.), Readings on Islam in Southeast Asia (Singapore: Institute of Southeast Asian Studies, 1985), pp. 165-170.

10. See, Nurcholish Madjid, "The Issue of Modernization among Muslims in Indonesia: From a Participant's Point of View," Ahmad Ibrahim, Sharon Siddique, Yasmin Hussain (eds.), Readings on Islam in Southeast Asia, p. 383.

11. This observation refers to Ahmad Wahib's recollections of a discussion between a number of HMI activists with a former leader of Masyumi, Prawoto Mangkusasmito. See, Djohan Effendi and Ismet Natsir (eds.), Pergolakan Pemikiran Islam: Catatan Harian Abmad Wabib (Jakarta: LP3ES, 1981), especially PP. 145146 , and 150.

12. M. Dawam Rahardjo, "Tujuan Perjuangan Politik Ummat Islam di Indonesia," Panji Masyarakat, No. 85, August 1971. Cited from Muhammad Kamal Hassan, Muslim Intellectual Responses to "New Order" Modernization in Indonesia (Kuala Lumpur: Dewan Bahasa dan Pustaka, 1982), p. 101.

13. Djohan Effendi and Ismet Natsir (eds.), Pergolakan Pemikiran Islam, p. 149.

14. For Soekarno's views on Islam, see Surat-Surat Islam dari Endeb (Bandung: Persatuan Islam, 1936). Reprinted in Soekarno's Dibawab Bendera Revolusi, Volume I (Jakarta: Panitia Penerbit Dibawah Bendera Revolusi, 1964), pp. 325-344. See also, M. Thalib and Haris Fajar (eds.), Pembabaruan Fabam Islam di Indonesia: Dialog Bung Kamo - A. Hassan (Yogyakarta: Sumber Ilmu, 1985).

15. It is generally believed that Islamic teaching is permanent in nature. To understand its messages, however, particularly in the post-Muhammad era, requires thorough interpretation and reinterpretation as circumstances warrant. Within the intellectual tradition of Islam, this endeavor is called ijtibad. This is an act to acquire a deliberate independent judgment which is not only meant to uncover the meaning of the doctrines of Islam, but also to reveal their general principles.

16. The phrase is taken from Nurcholish Madjid's "Masalah Tradisi dan Inovasi Keislaman dalam Bidang Pemikiran, serta Tantangan dan Harapannya di Indonesia," a paper delivered at the Istiqlal Festival, Jakarta, 21-24 October 1991, p. 4.

17. On the position of HMI in Indonesia's Islamic ideological and political discourse, see Victor Tanja's "Himpunan Mahasiswa Islam: Its History and Its Place among Muslim Reformist Movements in Indonesia," Ph.D. Dissertation, Hartford Seminary Foundation, 1979. See also his Himpunan Mabasiswa Islam: Sejarab dan Kedudukannya di Tengah Gerakan Muslim Pembabaru di Indonesia (Jakarta: Sinar Harapan, 1982).

18. Djohan Effendi and Ismet Natsir (eds.), Pergolakan Pemikiran Islam, pp. 144-174.

19. Among other members of this discussion group were Syu'bah Asa, Saifullah Mahyuddin, Djauhari Muhsin, Kuntowijoyo, Syamsuddin Abdullah, Muin Umar, Kamal Muchtar, Simuh, Wadjiz Anwar. See Mukti Ali's foreword in Pergolakan Pemikiran Islam, p. vii. Part of this information was also obtained from my interviews with Kuntowijoyo, Ichlasul Amal, Djohan Effendi and Dawam Rahardjo 
conducted in Yogyakarta and Jakarta between July and August 1991.

20. Djohan Effendi and Ismet Natsir (eds.), Pergolakan Pemikiran Islam, especially pp. 1-193.

21. See Mukti Ali's foreword at Pergolakan Pemikiran Islam, p. viii.

22. For a concise account on Mukti Ali's socio-intellectual origins, see Howard M. Federspiel, Muslim Intellectuals and National Development in Indonesia (New York: Nova Science Publishers Inc. 1992), pp. 19-22.

23. Interview with Djohan Effendi in Jakarta, 26-27 August, 1991. See also, Djohan Effendi and Ismet Natsir (eds.), Pergolakan Pemikiran Islam, pp. 149 and 155.

24. M. Dawam Rahardjo, "Tujuan Perjuangan Politik Ummat Islam di Indonesia."

25. Djohan and Ismet Natsir (eds.), Pergolakan Pemikiran Islam, pp. 146 and 150.

26. Djohan Effendi and Ismet Natsir (eds.), Pergolakan Pemikiran Islam, pp. 19-20, 69, 110-111, 121-126.

27. Djohan Effendi and Ismet Natsir (eds.), Pergolakan Pemikiran Islam, pp. 33-43, 46-48, 90-91. See also Djohan Effendi, "Pluralisme Pemahaman dalam Perspektif Theologi Islam," M. Masyhur Amin (ed.), Teologi Pembangunan: Paradigma Baru Pemikiran Islam (Yogyakarta: LKPSM NU DIY, 1989), pp. 149-152; Djohan Effendi, "Pluralisme Pemikiran dalam Islam," unpublished paper, August, 1987; Djohan Effendi, "Persekusi Ataukah Persuasi?" unpublished paper, February, 1986.

28. Interview with Djohan Effendi in Jakarta, 26-27 August 1991. See also Djohan Effendi and Ismet Natsir (eds.), Pergolakan Pemikiran Islam, pp. 144-156.

29. The event was organized by Utomo Dananjaya and Usep Fathuddin, respectively the national chairman and secretary general of PI. On this occasion, Nurcholish was actually a substitute for Alfian, a new graduate from the University of Wisconsin, whose doctoral dissertation discussed the issue of Islamic modernism in Indonesian politics during the Dutch colonial period with Muhammadiyah as its special case. Interview with Nurcholish Madjid, Montreal, 3 November 1991. Alfian's dissertation is "Islamic Modernism in Indonesian Politics: The Muhammadiyah Movement during the Dutch Colonial Period," Ph.D. Dissertation, University of Wisconsin, 1969. In 1989, this dissertation was published by Gadjah Mada University Press under the title Muhammadiyab: The Political Bebavior of a Muslim Modernist Organization Under the Dutch Colonialism.

30. Nurcholish Madjid, "Keharusan Pembaharuan Pemikiran Islam dan Masalah Integrasi Ummat," Nurcholish Madjid et al., Pembaharuan Pemikiran Islam, Jakarta: Islamic Research Center, 1970, pp. 1-12.

31. Nurcholish Madjid, "Keharusan Pembaharuan Pemikiran Islam dan Masalah Integrasi Ummat," p. 4.

32. Nurcholish Madjid, "Keharusan Pembaharuan Pemikiran Islam dan Masalah Integrasi Ummat," pp. 4-9.

33. According to Nurcholish his understanding of the Islamic monotheist principle (al-Tawbid) was largely shaped by his experiences accumulated during his visits to a number of Muslim countries, particularly Saudi Arabia, in the late 1960s. Because of the country's orientation to the Wahabiate theological school, which is obsessed with religious purification, the vast majority of its inhabitants adhere to a radical understanding of al-tawhid. This roughly means that nothing is sacred except Allah. In 1969, following his return from these trips, he articulated this radical notion of Islamic monotheism in his Nilai-Nilai Dasar Perjuangan (NDP). Later, after undergoing minor revisions with the help of Endang Saifuddin Anshari 
and Sakib Mahmud, it became the ideological manual of HMI. Interview with Nurcholish in Montreal, 3 November 1991. To date, while its content remains largely the same, the title has been changed to Nilai Identitas Kader (NIK). For this, see Hasil-Hasil Ketetapan Kongres Himpunan Mabasiswa Islam ke-16, March 1986, particularly pp. 74-123. It is important to note, however, that while Saudi Arabia does not seem to expand such a perception to the socio-political domains, Nurcholish does. Because of this, Saudi Arabia virtually adheres to the idea of legal/formal unity between Islam and the state.

34. Interview with Nurcholish Madjid in Montreal, 3 November 1991. See also "Nurcholish, yang Menarik Gerbong," Tempo, 14 June 1986, pp. 60-62.

35. Nurcholish Madjid, "Keharusan Pembaharuan Pemikiran Islam dan Masalah Integrasi Ummat, ${ }^{n}$ p. 2.

36. Interview with Munawir Sjadzali in Jakarta, 6 September 1991.

37. Interview with Munawir Sjadzali in Jakarta, 6 September 1991.

38. See, "Pembaharuan: Aplikasi Tanpa Kehilangan Esensi," Panji Masyarakat, No. 436, 1 July 1984, pp. 12-13.

39. Munawir Sjadzali, "Reaktualisasi Ajaran Islam," Iqbal Abdurrauf Saimima (ed.), Polemik Reaktualisasi Ajaran Islam (Jakarta: Pustaka Panjimas, 1988), pp 1-11.

40. See, Munawir Sjadzali, "Dinamika dan Vitalitas Hukum Islam," Panji Masyarakat, No. 459, 21 February 1985, pp. 25-28. See also his "Shari'a: A Dynamic Legal System," a paper presented at a conference on Shari'a and Codification, Colombo, Sri Lanka, December 1985; and his "Gejala Krisis Integritas Ilmiah di Kalangan Ilmuwan Islam," Pelita, 24 and 25 July 1987.

41. There are a number of Qur'ânic verses which can be used to support this statement. The one most fashionably referred to is the Qur'ân 16:89 which reads: "And We reveal the Scripture unto thee as an exposition of all things, and a guidance and a mercy and good tidings for those who have surrendered (to Allah)." Translation is from Marmaduke Pickthall's The Glorious Koran (Albany: State University of New York Press, 1976).

42. For a useful description of their political ideas, see, among others, Munawir Sjadzali, "Indonesia's Muslim Parties and their Political Concepts," M.A. Thesis, Georgetown University, 1959; Harun Nasution, "The Islamic State in Indonesia: The Rise of the Ideology, the Movement for Its Creation and the Theory of the Masyumi," M.A. Thesis, McGill University, 1965; Ahmad Syafii Maarif, "Islam as the Basis of State: A Study of the Islamic Political Ideas as Reflected in the Constituent Assembly Debates," Ph.D. Dissertation, University of Chicago, 1982. See also his Islam dan Masalah Kenegaraan: Studi tentang Percaturan dalam Konstituante (Jakarta: LP3ES, 1985).

43. See his "Indonesia's Muslim Parties and Their Political Concepts," MA Thesis, Georgetown University, 1959.

44. Munawir Sjadzali, Islam dan Tata Negara: Ajaran, Sejarab dan Pemikiran (Jakarta: UI Press, 1990).

45. Interview with Munawir Sjadzali in Jakarta, 6 September 1991.

46. See, his Islam dan Tata Negara: Ajaran, Sejarab dan Pemikiran (Jakarta: UI Press, 1990). See also "Kita Ini Kurang Berani," Tempo, 20 October 1990, pp. 96-97.

47. Based on their interpretation of Muhammad's farewell speech, the Shi'i claimed that the Prophet had actually publicly indicated that Ali ibn Abi Talib, his cousin and son-in-law, should succeed his political leadership. For a concise account on 
this issue, see Seyyed Hossein Nasr, Mubammad: Man of Allab (London: Muhammadi Trust, 1982).

48. Munawir Sjadzali, Islam dan Tata Negara, pp. 21-28. See also "Kita ini Kurang Berani," Tempo, 20 October 1990, pp. 96-97.

49. On the Constitution of Medina, see Muhammad Husayn Haykal, The Life of Muhammad, translated by Isma'il Ragi al-Faruqi, (North American Publications, 1976), pp. 180-183; Ibn Hisham, The Life of Mubammad, a translation of Ishaq's Sirat al-Rasul Allah, with introduction and notes by A. Guillaume (Lahore: Oxford University Press, 1970), pp. 231-233; W. Montgomery Watt, Muhammad at Medina (Oxford: The Clarendon Press, 1956), pp. 221-228.

50. Munawir Sjadzali, Islam dan Tata Negara, p. 16.

51. According to Munawir Sjadzali, other parameters of a theocratic state include (1) the making of the Holy Scriptures as the source of the law of the land; and (2) that the state leadership is in the hands of religious leaders. These parameters must converge together in a state to be called a theocratic state. For details of this account, see his "Negara Pancasila Bukan Negara Agama dan Bukan Negara Sekuler," unpublished paper, n.d.

52. In general, Maududi argues that the state is an integral part (or extension) of Islam. In his view, Islam sets forth its own concept of the state and system of governing. On the political theory of Mawdudi, see his The Islamic Law and Constitution, translated and edited by Khurshid Ahmad (Lahore: Islamic Publications, 1977).

53. On the political theory of Ali ibn Abd al-Raziq, see his. Al-Islâm wa Usùl al-Hukm (Beirut: Dar Maktabah al-Hayah, 1966); See also his Al-Islâm wa Qawấ id al-Sultân.

54. Munawir Sjadzali, Islam dan Tata Negara, pp.137-145 and 157-179; see also "Kita ini Kurang Berani," Tempo, 20 October 1990, pp. 96-97.

55. The idea of the finality of the current form of the Indonesian state originated from NU. In 1984, following the organization's 27 th conference, NU declared publicly that the Republic of Indonesia is the final goal for Indonesian Muslims in their ventures to devise the best possible form of the state. It was widely believed that the intellectual figures behind this pronouncement were the late Aclamad Siddiq and Abdurrahman Wahid. See, for instance, "Pimpinan PB NU Bertemu Presiden: Negara RI adalah Bentuk Final," Kompas, 15 February 1985. See also Munawir Sjadzali, "Wawasan Perjuangan Muslim Indonesia," a paper delivered at the commemoration of HMI's 43rd dies natalis, Yogyakarta, 4 February 1990, p. 2.

56. For Munawir Pancasila reflects the basic principles of political Islam. Interview with Munawir Sjadzali in Jakarta, 6 September 1991.

57. See his "Negara Pancasila Bukan Negara Agama dan Bukan Negara Sekuler," unpublished official speech, n.d.

58. Munawir Sjadzali, “Agama Sebagai Landasan Spiritual, Etik dan Moral Pembangunan," a keynote address delivered at the Manggala Training Forum, Bogor, 12 June 1990.

Bahtiar Effendy is a researcher at the Center for Policy and Develop. ment Studies (CPDS), Jakarta. 